\title{
Tratado sobre as cenas
}

\section{Sebastiano Serlio}

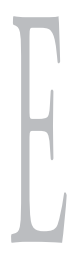

ntre outras coisas feitas pela mão dos homens, que se podem olhar com grande contentamento de olho e satisfação de alma, é (como me parece) o descobrir o aparato de uma cena, onde se vêem, em um pequeno espaço feito pela arte da perspectiva, soberbos palácios, amplíssimos templos, diversas casas ${ }^{1}$, de perto e de longe ${ }^{2}$ espaçosas praças ornadas de vários edifícios, retíssimas e longas estradas cruzadas por outras vias, arcos triunfais, altíssimas colunas, pirâmides, obeliscos, e mil outras coisas belas, ornadas de infinitos lumes ${ }^{3}$, grandes, médios e pequenos, segundo o que a arte comporta, os quais são tão artificiosamente ordenados, que representam tantas jóias lucidíssimas ${ }^{4}$, como se fossem diamantes, rubis, safiras, esmeraldas, e coisas semelhantes. Às vezes se vê a cornuda e lúcida lua levantar-se pouco a pouco, sendo alçada sem que os olhos dos espectadores a tenham visto mover-se; em outras se vê levantar o sol, o seu girar, e no fim da comédia pôr-se depois com tal artifício ${ }^{5}$, que muitos espectadores ficam estupefatos com tal coisa. Com o artifício apropriado se verá descer um deus do céu, correr algum planeta pelo ar, virem depois à cena diversos intermédios ${ }^{6}$ riquissimamente ornados, livrée $^{7}$ de várias sortes, vestes estranhas, tanto para a mourisca ${ }^{8}$, como para as músicas. Ora se vêem estranhos animais, dentro dos quais há homens e meninos movimentando-se, saltando e correndo tão bem ${ }^{9}$, não sem maravilhamento dos espectadores, coisas todas que dão tanto contentamento ao olho e à alma, que não se poderia imaginar coisa material, e feita pela arte, mais bela; e das coisas que pertencem à arte da perspectiva, eu tratarei um tanto. Ainda que este modo de perspectiva de que falarei seja diferente das regras, imaginadas sobre parede plana, por ser material e de relevo ${ }^{10}$, é bem razoável tomar-se outra estrada.

Primeiramente, é uso comum fazer-se um solo tão elevado da terra quanto nosso olho, isto é, partindo-se em nove partes todo o plano, a parte de trás se faz a nona parte mais alta do que a da frente. Seja elevado o referido solo da parte de trás em direção ao horizonte, e seja bem plano e forte por causa da mourisca; achei cômoda essa inclinação por experiência própria, porque em Vicenza (cidade muito rica e a mais pomposa ${ }^{11}$ ), fiz um teatro, e uma cena de madeira, porventura (aliás, sem dúvida) a maior

* Este Tratado encontra-se no segundo livro De Arquitetura e Perspectiva, de Sebastiano Serlio. Para a tradução utilizo Tutte l'Opere d'Architettura et Prospetiva di Sebastiano Serlio, Venetia, Giacomo de Franceschi, 1619. Fac-símile New Jersey, The Gregg Press, 1964. Tradução de Vânia Cristina Cerri. 
que nos nossos tempos se tenha feito, onde, pelos maravilhosos intermédios que lá aconteciam, como carretes ${ }^{12}$, elefantes, e diversas mouriscas, fiz com que diante da cena inclinada houvesse um só plano: a largura era de doze pés, e o comprimento de sessenta pés; achei-o bem cômodo e de grande aspecto. Este primeiro solo, sendo plano, seu pavimento não obedece ao horizonte, mas os seus quadros eram perfeitos e, ao começar o plano inclinado, todos os quadros iam para o horizonte, que com a devida distância diminui. E porque alguns puseram o horizonte na última parede, que termina a cena, necessariamente o puseram sobre o próprio solo, no embasamento dessa parede - o que mostra que todas as casas se juntam; imaginei ultrapassar o horizonte, no que fui tão bem-sucedido que, ao fazer tais coisas, tenho sempre seguido esta estrada, e, assim, aconselho os que com tal arte se deleitaram, a seguir o caminho que na carta seguinte mostrarei, e de que já tratei no perfil do teatro e da cena. E porque os aparatos ${ }^{13}$ das cenas são de três maneiras ${ }^{14}$, isto é, a cômica, a trágica e a satírica ${ }^{15}$, tratarei no presente da cômica, do casario que se destina a personagens privadas, com seus aparatos, que em sua maior parte se póem em uma sala, na extremidade da qual haja câmaras para a comodidade dos dizedores, e ali se faz o solo, como eu disse atrás, e mostrei o perfil, e adiante mostrarei a planta. Em primeiro lugar está a parte $\mathrm{C}$, que é o solo plano, onde, supondo que um quadro tenha dois pés, do mesmo modo os do plano inclinado têm dois pés para cada lado, sendo designado B; e (como eu disse no perfil) não pretendo pôr o horizonte na última parede da cena, mas o mesmo tanto do começo do plano B até a parede seja ultrapassado além da parede, como as duas linhas de pontos denotando uma parede na extremidade dessa sala: e assim todas as casas e outras coisas terão mais doçura ${ }^{16}$ nos seus escorços, onde, direcionados todos os quadros a esse horizonte, e diminuídos segundo a distância, se elevarão sobre as casas, que são as linhas grossas no plano reto e transversal, e estas casas, eu as fiz sempre de painéis sobre os quais tirei $^{17}$ telas, fazendo suas portas em fachada e em escorço, segundo a ocasião, e também fiz algumas coisas de baixo-relevo de madeira, que ajudaram muito as pinturas, como no lugar apropriado tratarei. Todo o intervalo dos painéis até a parede assinalado A servirá para os dizedores, e sempre a parede última tem de ser afastada das outras paredes ao menos dois pés, dessa maneira os dizedores podem passar protegidos; depois, o quão alto estiver o horizonte, seja elevado um grau a partir do princípio do plano $\mathrm{B}$, que será $\mathrm{L}$, e dalí ao horizonte seja tirada uma linha pontilhada, nível em que tocará a última parede; ali estará o horizonte desta parede e não servirá para outro painel, mas que a referida linha seja uma coisa estável, porque esta servirá a todos os painéis que estarão em majestade $^{18}$, para descobrir a grandeza de algumas coisas: mas o primeiro Horizonte além da parede servirá a todos os escorços das casas. E porque para fazer isto seria necessário romper essa parede, o que não se pode fazer, eu sempre fiz um pequeno modelo de cartão e madeira, bem medido e transportado depois para a escala grande, de coisa em coisa justamente com facilidade. Mas esta lição talvez para alguns seja difícil e, contudo, será necessário afadigar-se muito no fazer os modelos e experiências, pois estudando encontrar-se-á a via ${ }^{19}$. E porque as salas (por maiores que sejam) não tenham capacidades para teatros, eu, contudo, para aproximarme quanto possa dos antigos, quis fazer deste teatro a parte que possa caber em uma grande sala; não obstante, a parte $\mathrm{D}$ servirá para a praça da cena, a parte circular designada E será a praça do teatro, elevada um grau da praça da cena, em torno da qual haverá assentos para os mais nobres, que são F; os primeiros degraus $G$ são para as damas mais nobres, a parte $\mathrm{H}$ é a estrada, e assim a parte I e G, entre outros degraus, são para homens menos nobres, em meio aos quais há escadas para se sair mais comodamente. Os lugares espaçosos designados por $\mathrm{K}$ serão pois para a plebe e serão maiores ou menores segundo os lugares, e quanto maior o lugar, mais perfeita será a forma do teatro. 


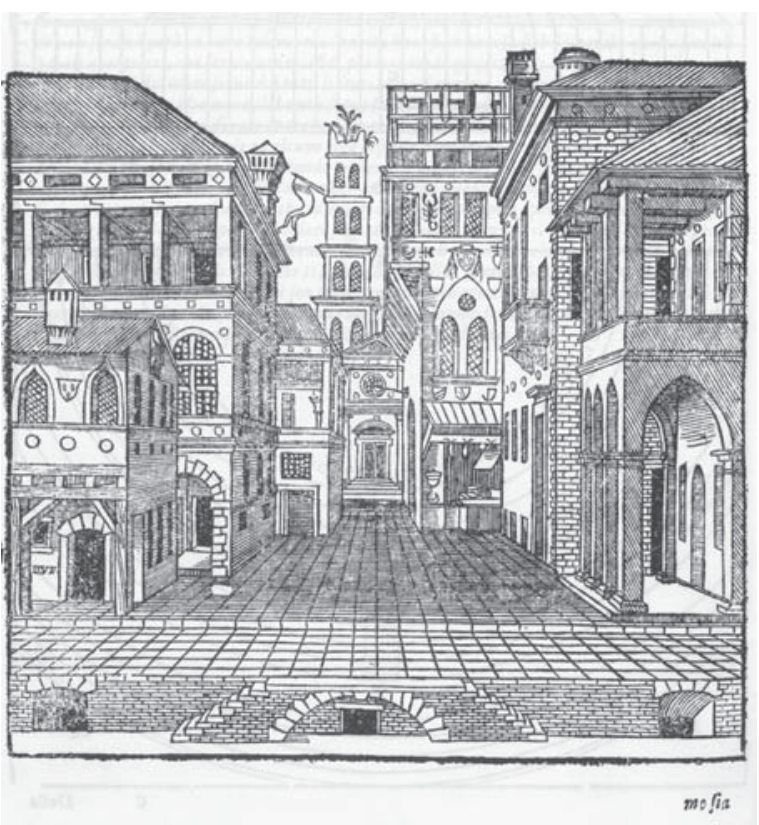

\section{Da cena cômica}

Quanto à disposição dos teatros e das cenas no concernente à planta, eu o tratei atrás; ora, das cenas em perspectiva, tratarei particularmente, e porque (como eu disse) as cenas se fazem de três sortes ${ }^{20}$, isto é, a cômica para representar comédias, a trágica para as tragédias, e a satírica para as sátiras: a primeira será a cômica ${ }^{21}$, cujas casas serão de personagens privadas, como o dos citadinos, advogados, mercadores, usurários, e outros semelhantes. Mas sobretudo que não falte a casa da rufiã, nem a taverna, e um templo é muito necessário; para dispor as casas no plano chamado solo: dei o modo atrás, tanto no erguer as casas sobre os planos, como na planta da cena, sobretudo como e onde se deve pôr o horizonte. Contudo, para que alguém seja mais bem instruído acerca das formas das casas, eu mostro ao lado uma figura que poderá dar um pouco de luz para quem com tal coisa queira deleitar-se. Por ser esta tão pequena, não pude observar todas as medidas; mas somente aludi a esta invenção para advertir que se faça a eleição das casas, de modo que, realizado, dê bom resultado, como um pórtico perfurado atrás do qual se veja outra casa como o primeira, cujos arcos são obra moderna ${ }^{22}$. Os balcões, uns dizem pérgolas, outros, parapeitos, têm grande efeitos nas fachadas que estão dispostas em escorço, bem como algumas cornijas cujos acabamentos ressaltando dos cantos, e acompanhando as outras cornijas pintadas produzem grande efeito: assim as casas que têm grande sacada para fora são bem realizadas, como a taverna da lua aqui presente ${ }^{23}$; e sobre todas as outras coisas se devem eleger as casas menores pondo-as à frente, a fim de que acima delas se descubram outros edifícios, como se vê na casa da rufiã, em cujo letreiro há ganchos, digamos, cobres, e que, pela superioridade da casa de trás, representa grandeza e preenche mais essa parte da cena, o que não se faria diminuindo-a, pois se a extremidade das casas diminuísse uma após a outra, e ainda que as coisas aqui desenhadas tivessem um lume só de um lado, não obstante tornam-se melhores pondo-se o lume no meio; por isso a força dos lumes se põe no meio, pendendo sobre a cena, e todas as formas, redondas ${ }^{24}$ ou quadradas que se vêem pelos edifícios são lumes artificiados de várias tintas transparentes; e darei o modo como se devem fazê-los no fim deste livro, sendo bom pôr os lumes atrás das janelas que estão na fachada, mas que sejam de vidro ou ainda de papel, ou de tela pintada, para que fiquem bem. Mas se eu quisesse escrever todos os conselhos que em mim são abundantes acerca disso, eu seria talvez prolixo, porém eu as deixarei para o intelecto daqueles que em tais coisas se queiram exercitar. 


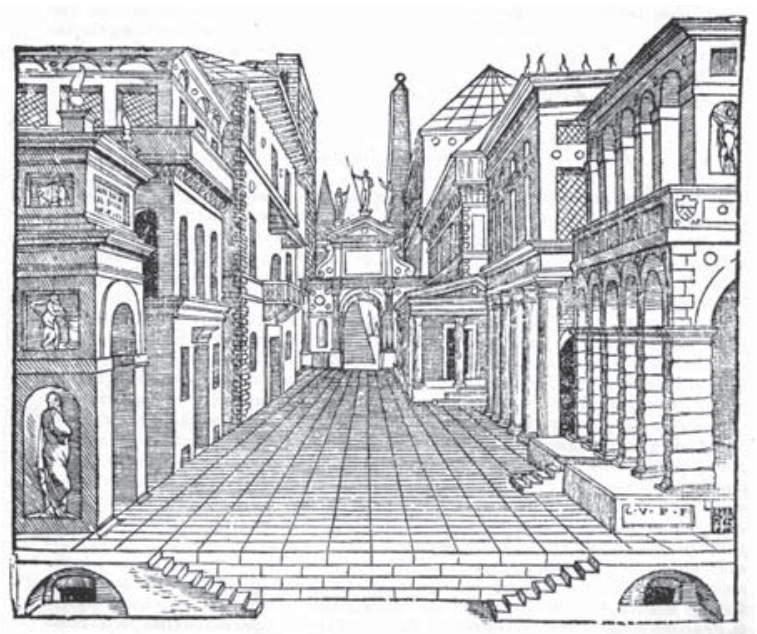

\section{Da cena trágica}

A cena trágica será para representar tragédias. ${ }^{25}$ Suas casas serão de grandes personagens; já que os acontecimentos amorosos e casos inopinados, mortes violentas e cruéis (como se lê nas tragédias antigas, e também nas modernas) ocorrem sempre na casa de senhores, duques, ou grandes príncipes, quando não de reis; portanto (como eu disse) em semelhantes aparatos não se fará edifício que não seja nobre, assim como se mostra na seguinte figura, na qual (por ser pequena) não pude mostrar os grandes edifícios reais e senhoris que em um lugar espaçoso se poderiam fazer ${ }^{26}$. Mas que isso baste ao arquiteto que sobre coisas semelhantes queira exercitarse para ter um pouco de luz sobre a invenção; e depois, para saber acomodar-se aos lugares, e ainda aos assuntos, e (como eu disse na cena cômica) se deve sempre fazer eleição das coisas que sejam melhores para o espectador ${ }^{27}$, não tendo receio em pôr um edifício pequeno diante de um grande, pelas razões já discutidas. E porque todas as minhas cenas eu as fiz sobre painéis, há por vezes algumas dificuldades, sendo então necessário servir-se do relevo de madeira, como o edifício ao lado esquerdo, cujas pilastras estão apoiadas sobre um embasamento com alguns degraus. Neste caso far-se-á o referido embasamento de baixo-relevo elevado sobre o plano, e depois se farão os dois painéis, isto é, o da fa- chada e outro em escorço, que estarão somente até o término da extremidade do parapeito que está sobre os primeiros arcos. Já que os arcos segundos se retraem para dar lugar ao parapeito; assim os dois painéis de cima se retrairão, de maneira que tal obra será bem acabada, e o que digo a respeito deste edifício se aplica ainda aos outros, no caso quando em alguma parte das casas se retraírem principalmente nos casos dos edifícios que estão aqui na frente. Mas quando tais coisas estivessem longe, uma tela só serviria, fazendo-se todas as partes bem delineadas e bem coloridas. Acerca dos lumes artificiados, eu disse o bastante na cena cômica. Todas as superfícies sobre os tetos, como as chaminés, campanários e coisas semelhantes (se bem que aqui não as haja) far-se-ão sobre uma tábua fina, recortadas, bem delineadas, e coloridas. Semelhantemente algumas estátuas, fingindo ${ }^{28}$ mármore $^{29}$, ou bronze, serão feitas de cartão grosso, ou também de tábua fina, bem sombreadas e recortadas, depois se porão em seus lugares: mas que estejam de tal maneira separadas e distanciadas que os espectadores não as possam ver de lado. Nestas cenas, embora alguns tenham pintado personagens que representam ${ }^{30}$ o que está vivo, como uma mulher em um balcão, ou atrás de uma porta, ou ainda algum animal, estas coisas eu não aconselho que se façam, porque não têm movimento e somente representam o que está vivo; mas uma pessoa que durma é um bom assunto, ou algum cão, ou outro animal que durma, porque não há movimento. Ainda se podem acomodar algumas estátuas ou outras coisas fingindo mármore, ou de outra matéria, ou alguma história ou fábula ${ }^{31}$ pintada sobre uma parede, que eu louvarei sempre se assim for feito. Mas no representar coisas vivas, que têm movimento, disso tratarei no final deste livro, e darei o modo como se devem fazê-las. 


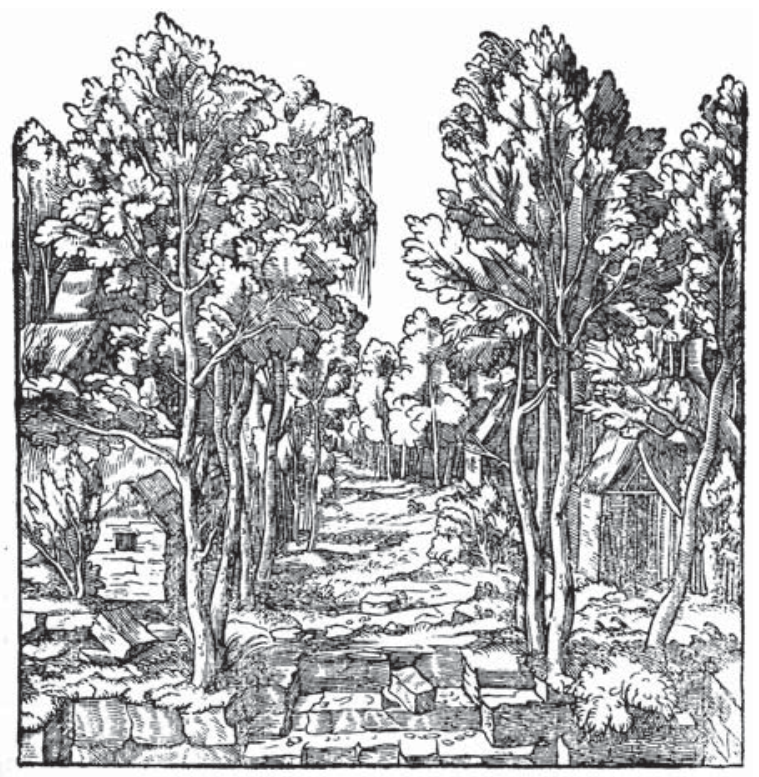

\section{Da cena satírica}

A cena satírica é para ${ }^{32}$ representar sátiras ${ }^{33}$, nas quais se repreendem (ou melhor, se mordem) ${ }^{34}$ todos os que vivem sem respeito e licenciosamente: nas sátiras antigas eram quase mostrados a dedo os homens viciosos e de má vida.

Também, se pode compreender que tal licença fosse concedida a personagens que sem respeito falassem, gente rústica ${ }^{35}$, como se dizia, por isso Vitrúvio, tratando das cenas, quer que sejam ornadas de árvores, pedras, colinas, montanhas, ervas, flores e fontes ${ }^{36}$, quer ainda que aí haja algumas cabanas à maneira rústica, como em seguida se mostra. E porque no nosso tempo estas coisas por mais das vezes se fazem na invernada ${ }^{37}$, onde poucas árvores e ervas com flores se encontram, poder-se-á bem artificiosamente fazer coisas semelhantes de seda, as quais serão ainda muito mais louvadas que as naturais ${ }^{38}$ : por isso, assim como nas cenas cômicas e trágicas se imitam as casas e outros edifícios com o artifício da pintura, também se poderão perfeitamente imitar as árvores e ervas com flores. E nestas coisas, quanto maior for o dispêndio, tanto mais louváveis serão: porque, na verdade, são próprias dos generosos, magnânimos e ricos senhores, inimigos da bruta avareza ${ }^{39}$. Já vi com meus próprios olhos em algumas cenas ordena- das pelo perito arquiteto Girolamo Genga ${ }^{40}$, a pedido de seu patrão Francesco Maria, duque de Urbino, onde presenciei tanta generosidade no príncipe, tanto juízo e arte no arquiteto, e tanta beleza nas coisas feitas, quanto eu jamais havia visto em outra obra feita pela arte (ou por deus imortal). Que magnificência era aquela, ver tantas árvores e frutas, tantas ervas e flores diversas, todas essas coisas feitas de finíssimas sedas de variadas cores, as ribanceiras, e as rochas copiosas, diversas conchas marinhas, caracóis e outros animaizinhos, troncos de corais de muitas cores, madrepérolas, e caranguejos marinhos cravados nas pedras, com tanta diversidade de coisas belas, que se eu quiser escrever tudo serei muito extenso nesta parte. ${ }^{41} \mathrm{Sem}$ falar dos sátiros, das ninfas, das sereias, e diversos monstros ou animais estranhos feitos com tal artifício, que se ajustam sobre homens e meninos segundo o tamanho de cada um, os quais, andando e movendo-se segundo a sua natureza, representavam esses animais vivos. E se eu não fosse demasiado prolixo, contaria dos trajes soberbos de alguns pastores, feitos de ricos tecidos, de ouro e de seda, forrados de finíssimas peles de animais selvagens. Diria ainda sobre as vestes de alguns pescadores, as quais não foram menos ricas que as outas, suas redes eram de fio de ouro fino, e os outros seus instrumentos eram todos dourados. Falaria ainda sobre algumas jovens pastorinhas e ninfas, cujos trajes desprezavam a avareza. Mas deixarei todas estas coisas ao intelecto de judiciosos arquitetos, que sempre farão tais coisas quando encontrarem semelhantes patronos conformes com suas vontades, e que lhes darão plena licença, com mão larga para operar tudo aquilo que quiserem. 


\section{Dos lumes artificiais das cenas}

Prometi atrás, nos tratados das cenas, expor a maneira pela qual se fazem os lumes artificiais de variadas tintas ${ }^{42}$ transparentes, por que primeiramente falarei sobre a cor ${ }^{43}$ celeste, que representa a safira e ainda muito mais bela. Pega um pedaço de sal amoníaco, e tem uma bacia de barbeiro ou outra vasilha de latão, pondo nela um dedo de água. Depois vai esfregando bem este pedaço de sal no fundo e em volta ${ }^{44}$ desta bacia, até que se consuma todo, acrescentando-lhe água sempre; e se quiseres maior quantidade desta água, e para que a tinta seja mais bela, aumenta a quantidade de sal amoníaco. Feita então uma bacia cheia desta água salgada, passa por um feltro para outra vasilha, e terás cor celeste belíssima. Mas, querendo-a mais clara, acrescenta a ela água pura, assim desta única tinta farás muitas, tanto mais claras e mais escuras quanto queiras, e se desta mesma água safirina quiseres fazer a cor de esmeralda ${ }^{45}$, põe nela um tanto de açafrão, um pouco mais, um pouco menos conforme a queiras mais escura ou mais clara. Destas coisas não te dou as proporções, mas com a experiência as farás de muitas sortes, ou claras, ou então escuras. Se quiseres fazer tinta de rubi, farás em lugar onde haja vinhos vermelhos carregados de tinta, e claretes, serão de rubis maduras e claras, isto é, acerbas, e se não tiveres vinhos, pega pau-brasil cortado em pedacinhos, pondo-o em uma caldeira cheia de água, com um tanto de pedraume, e a farás ferver espumando-a, e depois passar pelo feltro, acrescentando-lhe água pura se quiseres tinta mais clara, e se quiseres cor de balache ${ }^{46}$, o vinho rose, branca e vermelha juntas darão tal tinta, assim como os vinhos brancos mais ou menos carregados farão cores de crisópraso $^{47}$ e de topázio ${ }^{48}$. Mas (sem dúvida alguma) a água pura passada pelo feltro imitará os diamantes ${ }^{49}$. Porém, para fazê-los, será necessário fazer de madeira formas pontiagudas, e no forno dos vidros fazer bolhas que adquiram tais formas, e se encham de água. Mas o modo de dispor essas tintas transparentes será o se- guinte: haverá, por trás das coisas coloridas por estas tintas, uma tábua fina perfurada de modo que sejam distribuídos os lumes, sob a qual haverá outra tábua para sustentar as bolhas de vidro cheias dessas águas, depois se porão as referidas bolhas com a parte mais curva apoiada nesses furos, e bem seguras, para que não caiam com os estrépitos das mouriscas; e atrás das bolhas se porá uma candela, ou lâmpada, a fim de que o lume seja sempre igual, e se as bolhas voltadas para a lâmpada forem planas, ou até mesmo côncavas, receberão melhor a luz, e as tintas serão mais transparentes; do mesmo modo, para as formas redondas ${ }^{50} \mathrm{em}$ escorço ${ }^{51}$, serão feitas bolhas dessa sorte. Mas, se às vezes convier um lume grande e galhardo, por-se-á uma tocha atrás de uma bacia de barbeiro bem polida e nova, cujo reflexo produzirá certos esplendores, como os raios do sol. E se alguns lugares forem amendoados, ou de outras formas, pregar-se-ão placas de vidros de variadas cores nestes lugares, e um lume por trás. Mas estes lumes não serão porém os que irão iluminar a cena; por isso grande cópia de tochas se pendura diante da cena. Poder-se-á ainda sobre a cena pôr algumas candeias com tochas, e em cima dessas candeias haja ainda uma vasilha cheia de água, na qual porás um pedaço de cânfora, que, ardendo, dá belíssimo lume, e é odorífica. Às vezes convirá mostrar alguma coisa que queime (o que quer que seja), banhando-se bem com aguardente das mais potentes, e acendendo-se a chama com uma candelinha; desse modo arderá por um tempo. Embora, quanto aos fogos, tenha podido falar muito mais, que isto seja o bastante no momento. Mas falemos de algumas coisas que são de grande deleite aos espectadores. Enquanto a cena estiver vazia de dizedores, poderá o arquiteto preparar uma fileira de figuras cujo tamanho será determinado pelo lugar onde terão de passar, e estas serão de cartão grosso, coloridas e recortadas, presas a uma haste de madeira através da cena, onde haja um arco, e seja feito sobre o solo com um encaixe em casa$\mathrm{ca}^{52}$, no qual se porá a referida haste, e assim lentamente uma pessoa por trás do referido arco 
as fará passar, e às vezes mostrar-se-ão músicos com instrumentos e vozes, de modo que atrás desta cena haja uma música subentendida como voz. Outras vezes, uma multidão de gente correrá, uns a pé e uns a cavalo, que, com vozes ou gritos surdos, estrépitos de tambores, e som de trompas, apascentam ${ }^{53}$ muito os espectadores. E se às vezes acontecer que algum planeta ou outra coisa semelhante se veja passar pelos ares, que essa coisa seja bem pintada em cartão recortado e, depois, atrás da cena (isto é, no último casario), seja estendido um fio de metal fino, e nesse haja alguns aneizinhos presos atrás do cartão, onde haja um fio negro que será puxado devagarinho por uma pessoa que esteja do outro lado, mas que estará de tal sorte longe que nem um nem outro fio serão vistos. Às vezes ocorrerão trovões, raios e relâmpagos; a propósito, os trovões se farão da seguinte maneira: sempre (como eu disse) as cenas se fazem na extremidade de uma sala, no solo da qual correrá uma grande bola de pedra, que simulará corretamente o trovão. O relâmpago assim se fará: haverá alguém atrás da cena em lugar alto, tendo na mão uma caixinha onde haja pó de verniz, cuja tampa esteja cheia de furos, e no meio desta tampa haverá uma candelinha acesa, e erguendo a mão, o pó sairá para o alto, e percutirá na candela acesa de maneira que simulará relâmpagos muito bem. Quanto aos raios, ao longe será estendido um fio de ferro através da cena, de alto a baixo, onde será posto um carretel, e assim seja feito o raio, que será ornado de ouro brilhante; e enquanto se fará o trovão, seja solta um cabo e ao mesmo tempo seja posto fogo no raio, e ter-se-á um bom efeito. Mas se eu quisesse tratar de todas as coisas semelhantes que são em mim abundantes, eu seria mais prolixo, porém darei fim ao que concerne à perspectiva. 


\section{Notas}

1 O texto se inicia com o uso de preceitos da elocução, variedade e copiosidade, em que, instruindo, o orador agrada, comove e ensina o ouvinte, ou seja, a figuração da cena segue determinadas leis que correspondem ao discurso do orador, o qual retoricamente utiliza os elementos de variedade e copiosidade na disposição do texto, compondo aqui um exórdio para a captatio da benevolência no ouvinte. Cf. Quintiliano, Instituiçôes Oratórias, livro III, 8, 3. Trad. de J. Soares Barbosa. São Paulo: Cultura, 1944, p. 154; bem como Horácio, Arte Poética. Trad. de R. M. Rosado Fernandes. Lisboa: Editorial Inquérito, 1984, vv. 28-30: "Acaba, todavia, rastejando pelo chão o demasiado cauto, o que tem medo da procela; mas quem deseje variar prodigiosamente um tema uno, pintará golfinhos nas florestas e javalis nas ondas do mar.". Do mesmo modo Alberti no Da Pintura também segue esses autores, ao dizer que a primeira coisa que proporciona prazer na história é a variedade e a copiosidade das coisas; cf. Alberti, Leon Battista, Da Pintura, livro II. Trad. de A. Silveira Mendonça. Campinas: UNICAMP, 1992, p. 112.

2 Cf. Horácio, op. cit., vv. 361-365: "Como a pintura é a poesia: coisas há que de perto, mais te agradam e outras, se a distância estiveres. Esta quer ser vista na obscuridade e aquela à viva luz, por não recear o olhar penetrante dos seus críticos; esta só uma vez agradou, aquela, dez vezes vista, sempre agradará.” Do Ut pictura poesis se tirou uma doutrina genérica do decoro necessário para o gênero epidítico, segundo sua disposição. A categoria distância, utilizada nos termos 'de perto e longe' (si propius stes/si longius abstes), neste caso liga-se mais ao movere.

3 Do latim lumen: luz, meio de iluminação, candeia. Luz "que se vê", fogo.

4 Plínio diz que as pedras preciosas são definidas como obras da natureza. Aqui Serlio utiliza uma série crescente de qualificações, que compõem tanto um discurso ornado quanto a ornamentação da cena produzindo um maravilhoso deleite.. Há uma relação comparativa entre esses ornatos da cena, que são os lumes artificiosamente ordenados (obras que os homens realizam), e as pedras preciosas aqui representadas pelas jóias lucidíssimas (obras da natureza, segundo o livro XXXIV da História Natural, de Plínio). Deste modo Serlio eleva sua arte, definindo os ornatos enquanto imitação da própria natureza. Cf. também Pline l'Ancien, Histoire Naturelle, livro XXXVII. Trad. de E. de Saint-Denis. Paris: Les Belles Lettres, 1972, p. 34, 57 e 60: "Para que nada falte à obra que empreendemos, nos resta falar das pedrarias; nelas a majestade da natureza se concentra, e em nenhum domínio ela é mais admirável. Se fixa tanto valor a sua variedade, a suas cores, a sua matéria, a seu esplendor, que gravar certas gemas passa mesmo por sacrilégio. (..) O maior preço, entre os bens dos homens, e não somente entre as pedrarias, é atribuído ao diamante, que há tempos só os reis conheciam (...). Em terceiro lugar estão as esmeraldas, por várias razôes: o fato é que não há cor mais agradável aos olhos, porque também olhamos avidamente as verduras e as folhagens, mas a visão das esmeraldas é de tal modo mais agradável, que parece não haver em todos os verdes aquele que comparado a ela seja mais verde.”

5 Cf. Shearman, John, O Maneirismo. Trad. de O. Mendes Cajado. São Paulo: Cultrix, 1978, p. 18: "no século XVI, a palavra artifizioso, totalmente lisonjeira, acompanhava quase sempre a maniera; os livros deviam ser escritos, e os quadros pintados com artifício.”

6 Intermédio teatral (intermezzo), pequena composição teatral que se representava nos intervalos dos atos, no começo ou no fim dos espetáculos. Cf. Shearman, J., op.cit., p. 109 e 116: "Os intermezzi de Ferrara, por volta de 1500, eram relativamente discretos: recitativos curtos, coros (como, por exemplo, os strambotti) ou danças (moresche), com temas narrativos, simples ou alegóricos (...). Os intermezzi eram tableaux vivants (...). Acima de tudo, a relação diferente entre esses tableaux e o espectador caracterizava o "maneirismo"'.

7 Livrée: libré, veste fornecida pelo senhor ao servo. Divisa usada por dependentes das grandes casas senhoriais, como camareiras e cocheiros. Mantive o termo francês que Serlio empregou. 
8 Dança difundida na Europa no Renascimento, de origem incerta. Na dança mourisca os figurantes se vestem de mouros e portam armas e emblemas à maneira dos mouros. A mourisca é mencionada neste texto várias vezes, podendo Serlio tê-la utilizado também para compor o que ele chama de 'obra moderna'. Segundo Grassi, Luigi \& Pepe, Mario, Dizionario dei Termini Artistici. Torino: UTET, 1994, p. 547, no século XVIII foi estabelecida uma relação entre "obra moderna", denominada "gótico moderno", e o mouresco.

9 Alberti evidencia os preceitos de variedade e copiosidade, empregados em textos latinos, enquanto preceitos para a figuração do gênero da história na pintura. Serlio também utiliza estes preceitos na composição de uma cena ornada, por meio da representação variada e copiosa das personagens, em açōes adequadas. Cf. Alberti, L.B., op. cit., livro II, p. 112-3: "A primeira coisa que proporciona prazer na história provém da variedade e copiosidade das coisas. Para mim é muito copiosa a história em que em seus lugares se misturem velhos, jovens, meninos, mulheres, meninas, criancinhas, frangos, gatinhos, passarinhos, cavalos, ovelhas, construções, províncias e todas as coisas semelhantes. Louvarei toda e qualquer riqueza que pertença à história. Acontece que a copiosidade do pintor acarreta muita satisfação - o espectador se detém a olhar todas as coisas. (...) Em qualquer história a variedade sempre é grata e sobretudo é agradável a pintura em que os corpos e suas poses sejam bem diferenciados." Cf. também Horácio, op. cit., vv. 155-158: "Deves fazer ressaltar os caracteres de cada idade, e não deve faltar propriedade às naturezas, que com os anos variam."

10 Aqui Serlio evidencia o modo de perspectiva cênica, que difere-se das regras passadas elaboradas para a arquitetura, por operar com a luz e sombra que ressaltam os volumes produzindo relevos, obtendo desse modo a maravilha dos efeitos da cena.

11 Ao designar Vicenza como uma cidade muito rica e pomposíssima, Serlio emprega a tópica na ação para articular o encômio. Ao mesmo tempo se vale da autorictas de Plínio, op. cit., livro XXXVII, p. 125: "em todo o mundo, onde quer que se estenda a abóbada celeste, a região que entre todas está mais guarnecida das vantagens que merecem o primeiro lugar na natureza é a Itália, rainha e segunda mãe do universo, por seus homens, suas mulheres, seus chefes, seus soldados, seus escravos, sua superioridade artística, a celebridade de seus engenhos, assim como por sua localização, a salubridade de seu clima temperado, os acessos fáceis que ela oferece a todas as nações". Cf. também Plínio, op. cit., livro XXXVI. Trad. de R. Bloch. Paris: Les Belles Lettres, 1981, p. 84: "Mas seria conveniente também ver as maravilhas de nossa cidade, examinar sua força dócil, e no curso de seus 800 anos de existência mostrar que, também neste domínio ela venceu o mundo inteiro. O mesmo tanto de vitória se verá nas maravilhas da cidade”.

12 Em português, 'carrete' é o termo mais aproximado do italiano 'carrette', pequenos carros com duas rodas e com borda alta.

13 Cf. Grassi, Luigi \& Pepe, Mario, op. cit., p. 52: "Apparato, Apparati - termo do século XVI que designa uma estrutura arquitetônica provisória, costumeiramente construída por ocasião de festa religiosa ou de cerimônia pública. (...) Uma das mais famosas notícias de um aparato é a que G. Vasari, servindo-se de um relato fornecido por G. B. Cini, põe no final de suas Vidas, com o título: Descrição do Aparato Feito em Firenze para as Núpcias do Ilustríssimo e Excelentíssimo Dom Francesco De Médici, Principe de Firenze e de Siena, e da Serenissima Rainha Giovanna D'Áustria. As festividades se prolongaram de dezembro de 1565 ao carnaval do ano seguinte, ocasião para uma completa e riquíssima decoração, (...) com motivos da antiguidade, em clima faustoso e retórico, com intenção declarada de enganar os olhos do espectador." Cf. ainda Vitrúvio, I Dieci Libri..., livro V, p. 256: "três são as espécies dos ornatos e aparatos; estas máquinas giram e mudam o aspecto dos ornamentos em cada fachada, de acordo com a mudança da fábula".

14 Utilizou-se (além de outras edições que serão mencionadas) para a consulta da obra de Vitrúvio, I Dieci Libri dell'Architettura di M.Vitruvio, tradução e comentários de Daniel Bárbaro; Venetia, Francesco de Franceschi, 1521, a qual mantive os termos utilizados no século dezesseis para comparação com o $D a$ arquitetura de Serlio. 
Segundo a edição consultada, de Vitrúvio, I Dieci Libri..., à p. 256 de Vitrúvio, livro V: Daniel Bárbaro, em sua tradução, ao falar dos aparatos de cenas utiliza o termo 'specie', o qual entendo como 'gênero' das cenas trágicas, cômicas e satíricas. "Havia partes à direita, e outras à esquerda, de modo que a fachada da cena tinha grandes nichos, como se vê na planta, em que eram erguidas máquinas triangulares que giravam sobre eixos, e em cada fachada era pintado o ornamento segundo a fábula que se deveria representar, porque uma fachada era a perspectiva de uma cena cômica, outra, a trágica, e outra, a satírica, e segundo a ocasião mudavam a fachada". Porém Sérlio utiliza o termo maniera para se referir ao aparato da cena, prescrevendo o uso e a admiração pela arte antiga como podermos ler na historiografia do século XVI. Esta hipótese se afirma na escolha da cena cômica para falar dos aparatos, a qual Serlio caracteriza como os elementos pertencentes a arquitetura "moderna".

15 Vitrúvio, I Dieci Libri..., livro V, p. 256: "Três são as sortes das cenas, uma é chamada cena trágica, a outra, cômica, e a terceira, satírica. Seus ornamentos são diversos entre si, e se fazem em compartimentos desiguais, porque as cenas trágicas se formam com colunas, frontispícios, figuras e outros ornamentos reais. As cômicas têm forma de edifícios privados, de pérgolas ou corredores, e perspectivas de janelas dispostas à imitação dos edifícios comuns, mas as cenas satíricas são ornadas com árvores, espeluncas, e jardins." Há uma divergência entre as duas ediçōes de Vitrúvio consultadas. Na tradução de Daniel Barbaro aparece o termo 'sorte de Scene'; na tradução contemporânea de Cesariano (Vitruvius, De Architetura, trans. from the Latin into Italian by Cesare di Lorenzo Cesariano, Como, 1521. Facsímile London, Benjamin Blom, 1968), aparece o termo 'generationes (gêneros) de Scené. Sérlio parece se valer da mesma disposição sobre o assunto, substituindo no primeiro momento os termos 'sorte' el ou 'generationes' por 'apparati' e, enquanto exemplo, escolhe tratar primeiramente das cenas cômicas, sendo que Vitrúvio inicia o tratamento das sortes de cena pela cena trágica.

16 Para traduzir dolcezza por 'suavidade', me pautei na leitura de Baxandall, Michael, O Olhar Renascente. Trad. de M.C.P.R. de Almeida. Rio de Janeiro: Paz e Terra, 1991, p. 192: "O método de Plínio se fundamentava muito largamente sobre uma tradição do uso de metáforas: ele descrevia o estilo dos artistas com palavras que deviam boa parte de seu significado a seu uso em contextos sociais ou literários, não pictóricos - austero, florido, duro, grave, severo, líquido e quadrado." Embora não utilizasse os termos de Plínio, Serlio parece ter conservado esse mesmo método, e aqui dolcezza estaria ligada à maniera do XVI.

17 Empreguei o termo "tirar" no sentido de estampar, fixar.

18 Majestade (maestá) é um lugar-comum do objeto de louvor. Cf. Quintiliano, op. cit., livro I, XIV, p. 113: "O louvor tem especialmente lugar nos deuses, e nos homens. Contudo outras coisas há, de que também se podem louvar, como os animais, e coisas insensíveis."

19 Mantive o termo 'estudo', porém no sentido que Vitrúvio apresenta em I Dieci Libri..., livro I, p. 32. : "De quais coisas é composta a arquitetura: pensamento, dedicação plena ao estudo e eficácia na indústria, e dedicação à obra proposta, com deleite."

20 Neste trecho [perché (come io dissi) le Scene si fanno di tre sorti], Serlio, ao falar da 'sorte' da cena cômica, remete aos 'aparatos' da cena mencionados anteriormente (Et perché gli apparati delle Scene sono di tre maniere); proponho manter o termo 'sorte' entendido como 'maneira'. No tratamento específico das sortes de cenas, Serlio utiliza-se do mesmo termo usado por Daniel Barbaro, tradutor e comentador de Vitrúvio; Serlio, porém, inicia o texto a partir da cena cômica e não da cena trágica, que Vitrúvio elege para começar seu texto, mantendo-se as correspondências no que concerne ao decoro de cada cena. Cf. Vitrúvio, I Dieci Libri..., livro V, VIII.

21 Na cena cômica Vitrúvio trata dos ornamentos dos 'edifícios privados', enquanto Serlio modifica-os acrescentando os termos 'personagens privadas'. Cf. Vitrúvio, I Dieci Libri..., livro V, p. 256: "As cenas cômicas têm forma de edifícios privados, de pérgolas, ou corredores, e perspectiva de janelas dispostas à imitação de um edifício comum." Cf. também, na mesma página, comentário de Daniel Barbaro 
que dá ênfase à cena à luz das açôes e do decoro das personagens segundo o gênero da comédia: "Os cômicos representavam coisas cotidianas, e ações de gente baixa, portanto esta cena imitava edifícios privados".

22 A crítica à arquitetura 'moderna' é assunto da historiografia do século XVI, e é tratada por Serlio como matéria pertencente ao gênero da comédia. Rafael, assim como outros contemporâneos a Serlio, considerava a maniera uma qualidade desejável encontrada nos edifícios antigos, onde a norma era proporcionada pelo vocabulário vitruviano, ausente porém nos edifícios chamados góticos. Cf. Rafael, Carta ao Papa Leão X, XI. Trad. de Luciano Migliaccio, cópia xerográfica: "Começou depois surgir quase por todas as partes a maneira da arquitetura alemã, que, como ainda se vê, nas ornamentações é muito longínqua da bela maneira dos Romanos. (...) Contudo, sua arquitetura teve alguma razão pois nasceu das árvores ainda não cortadas, às quais, dobrando os ramos e atando eles juntos, fazem seus arcos agudos." (grifo nosso)

23 Ver figura à página 46 da edição italiana, nos Anexos.

24 Optei por utilizar os termos 'formas redondas' pois não há um termo correspondente em português para o italiano tondi (adjetivo); não se trata aqui do termo determinado 'círculo' (enquanto geometria), mas do termo determinante 'redondo'.

25 Na cena trágica Serlio mantém o decoro antigo. Cf. Vitruvius, De Architetura, liber V, p. LXXXIII: "As cenas trágicas se formam com colunas, frontispícios, figuras e outros ornamentos reais. Os trágicos recitavam os casos dos tiranos e dos reis, a estes convinham ornamentos reais, palácios, peristilo, colunatas."

26 Cf. Vitrúvio, I Dieci Libri..., livro I, p. 36: "Mas a habitação dos grandes, que com graves pensamentos governam a república, deve ser fabricada para seu uso, em suma, a distribuição dos edifícios convém ser feita segundo as pessoas." Empregou-se o termo 'pessoas', correspondendo ao que em português designa condição.

27 Mesmo tratando do que é adequado ao gênero da cena trágica, Serlio não deixa de fazer menção à cena cômica para reforçar o que há de mais importante, a visão do espectador. Ressalto aqui a referência aristotélica; cf. Aristóteles, Poética. Trad. de Eudoro de Sousa. 2a ed., Lisboa: Imprensa Nacional, 1990, 49b30, p. 110.

28 No sentido de simulação, imitação (chave da mímesis aristotélica).

29 Serlio se vale da autoridade conferida por Plínio ao seu texto. Cf. Plínio, op. cit., livro XXXVI, p. 53: "Não esqueçamos que a escultura de mármore é bem mais antiga que a pintura ou a estatuária em bronze, que começaram ambas com Fídias, no curso da octogésima terceira olimpíada, cerca de 332 anos mais tarde. Segundo a tradição, o próprio Fídias trabalhou o mármore, havendo em Roma, nos monumentos de Otávio, uma estátua de Vênus feita por suas próprias mãos e de insigne beleza."

30 Mantive o termo 'representação' no sentido teatral, de pôr em ação uma peça, (comédia, tragédia, sátira), aplicando à pintura a prática teatral de imitação do objeto ou coisa a ser representada.

31 No tratamento da fábula, Serlio mantém o decoro antigo cuja fonte está no mito aristotélico; cf. Aristóteles, Poética, 50a8, p. 111: "É, portanto, necessário que sejam seis as partes da tragédia que constituam a sua qualidade, designadamente: mito, caráter, elocução, pensamento, espetáculo e melopéia. (...) Daqui se segue que, na tragédia, não agem as personagens para imitar caracteres, mas assumem caracteres para efetuar certas açōes; por isso, as ações e o mito constituem a finalidade da tragédia, e a finalidade é de tudo o que mais importa."

32 Deve haver aqui uma falha de impressão, porém, diante do que o texto diz sobre a cena cômica e trágica, proponho esta hipótese.

33 Vitrúvio, De Architetura, liber V, p. LXXX: "Mas as satíricas se ornam com árvores, espeluncas e montes, e outras coisas agrestes: em espécie de topiária obra deformada." 

"de 1509 a 1510 Girolamo Genga projetou em Urbino, para a solene chegada de Eleonora Gonzaga, esposa de Francesco Maria della Rovere, 'arcos triunfais, aparatos e cenas de comédia', exercendo uma influência determinante sobre Serlio. A cerca dessa montagem se baseia também a detalhada descrição da cena satírica feita por Serlio".

41 Aqui há o uso do preceito de variedade; embora o texto mencione a brevidade, define-se pela abundância. Cf. Shearman, J., op. cit., p. 159: "A abundância não era uma virtude só no sentido quantitativo; significava densidade de motivo tanto quanto excessividade." o termo 'tinta' e não 'cor' por se tratar aqui da maneira de produzir os lumes artificiais das cenas, por meio de matérias corantes das tintas e suas cores.

43 Optei pelo termo 'cor', em detrimento a 'tinta', por se tratar de nome de objeto cuja cor foi tomada por tipo, como, por exemplo, cor celeste.

44 Em torno; ação ou efeito de mexer o conteúdo de um recipiente.

45 Ver Plínio, op. cit., livro XXXVII, p. 60 e 64 : "Em terceiro lugar estão as esmeraldas, por várias razões: o fato é que não há cor mais agradável aos olhos, porque também olhamos avidamente as verduras e as folhagens, mas a visão das esmeraldas é de tal modo mais agradável, que parece não haver em todos os verdes aquele que comparado a ela seja mais verde. (...) [As esmeraldas] da Pérsia não são transparentes, mas sua agradável uniformidade de cores satisfaz à vista, assemelham-se aos olhos dos gatos e das panteras e, com efeito, sem ser transparentes brilham como eles. Ao sol elas empalidecem, na sombra elas refulgem e brilham bem mais que as outras."

46 Derivado do árabe Balakhch (espécie de rubi), nome dado pelos joalheiros a uma variedade de espinela cor-de-rosa ou violeta.

47 Crisópraso mineral, variedade de calcedônia de cor verde-maçã. Ver Plínio, op. cit., livro XXXVII, p. 82-3: "Há também muitas outras espécies de pedras verdes, dentre as mais comuns, o prásio; outra espécie se distingue por seu pontilhado cor de sangue e uma terceira é marcada por três riscos brancos. 
A preferida é o crisópraso, cuja cor lembra também o suco de alho-porro, mas tende um pouco para o verde-topázio sobre ouro.”

48 Ver Plínio, op. cit., livro XXXVII, p. 80: "O topázio tem até hoje grande prestígio devido à sua nuança verde, e desde que foi descoberto foi a preferida de todas as pedras."

49 Ver Plínio, op. cit., livro XXXVI, p. 57: "O maior preço, entre os bens dos homens, e não somente entre as pedrarias, é atribuído ao diamante".

50 Ver nota 24.

51 Encurtamento, diminuição.

52 Tipo de encaixe com uma extremidade que se alarga e termina em ponta.

53 Deleitar-se vendo, contemplando. 